\title{
Effects of Plant Growth Regulators on Shoot Regeneration and Callus Induction of Carica papaya $\mathrm{L}$.
}

\author{
Radzuan, N.S., Hasbullah, N.A., Patah, F.K.A., Idris, H. and Mohammad Mohd Lassim
}

\begin{abstract}
A study was conducted to test the effect of 16 different concentrations and combinations of Benzylaminopurine (BAP) and Napthalene-Acetic Acid (NAA) on 3 different types of Carica papaya L. explants, namely leaf, stem and root. The 16 different treatments were from combinations of BAP and NAA with concentrations of $0.0 \mathrm{mg} / \mathrm{L}, 0.5 \mathrm{mg} / \mathrm{L}, 1.0 \mathrm{mg} / \mathrm{L}$ and $2.0 \mathrm{mg} / \mathrm{L}$ respectively. Experiment involves seed sterilization and sub culturing of explants in different medium concentrations and combinations of BAP and NAA. Each treatment consisted of 30 samples, thus there were total 1440 explants culture in this experiment. The experiment had been conducted for 8 weeks, and the observation was recorded once in 4 weeks. Throughout the experiment, the development of callus, regeneration of shoot and formation of root were observed. At week 8, extra parameters were observed and recorded including weight of callus, number of shoot for each explant and number of root for each explant. The optimum medium concentration for shoot regeneration was MS medium + BAP $2.0 \mathrm{mg} / \mathrm{L}$ from stem explant with $3.800 \pm 0.098$ numbers of shoots per explant. Meanwhile, for callus induction, stem explant was observed to be the most responsive explant when cultured on MS medium + BAP $0.5 \mathrm{mg} / \mathrm{L}$ and NAA is $0.5 \mathrm{mg} / \mathrm{L}$. The data from week 8 was then analyzed by using SPSS version 23.
\end{abstract}

Keywords - regeneration; tissue culture; explant; Carica papaya L; MS medium

\section{INTRODUCTION}

Papaya is one of the major tropical fruits consumed in the world. It is estimated that Malaysia produces 35,600 tonnes papaya each year where 22,200 tonnes are exported to other parts of the world [1]. The increase in global demand for papaya has led to improvement in papaya quality and the

Nurul Shifa Radzuan ${ }^{1}$ is with Department of Agriculture Science, Faculty of Technical and Vocational (FTV), Universiti Pendidikan Sultan Idris (UPSI), Tanjong Malim, Perak, Malaysia.

Dr Nor Azlina Hasbullah ${ }^{2}$, is with Department of Agriculture Science, Faculty of Technical and Vocational (FTV), Universiti Pendidikan Sultan Idris (UPSI), Tanjong Malim, Perak, Malaysia.

Fadhlul Khaliq Ab Patah ${ }^{1}$ is with Department of Agriculture Science, Faculty of Technical and Vocational (FTV), Universiti Pendidikan Sultan Idris (UPSI), Tanjong Malim, Perak, Malaysia..

Prof. Dr. Mohammad Mohd Lassim is with Faculty of Sustainable Agriculture (Sandakan Campus), Universiti Malaysia Sabah (UMS), 90000, Sandakan, Sabah, Malaysia.

Husna Idris is with Department of Agriculture Science, Faculty of Technical and Vocational (FTV), Universiti Pendidikan Sultan Idris (UPSI), Tanjong Malim, Perak, Malysia. production in Malaysia. However, the production of papaya is threatened as the industry is affected by various diseases [1] such as the outbreak of the bacterial dieback disease in 2003. The papaya dieback disease had spread to six states in Malaysia by 2006 and had caused an annual loss of USD 58 million [2]. The disease is capable of destroying the papaya trees and cause yield loss.

Since the 1980s until now, plant tissue culture techniques have grown very rapidly. This situation has caused the culture activities difficult be monitored. Moreover, many breakthroughs have high commercial value achieved by research institutions from unpublished companies. In addition to plant propagation, the field of genetic engineering was aimed to improve the genetic quality of agricultural crops. There have been many varieties, even new species created through protoplast fusion techniques. Similarly, the application of the tissue culture techniques to the elimination of disease, especially viral diseases and secondary metabolite production with the help of Agrobacterium has become a routine technique performed by experts around the world [14].

There are many plants that have been successfully propagated through tissue culture system. Malaysian local fruit crops are among it, such as banana, star fruit, papaya and many others. The papaya is popular as a backyard tree in many developing countries but increasingly becoming more important in commercial plantings for domestic markets and in countries like Mexico and Malaysia, for export. Advantages in papaya cultivation include a rapid return to investment and intensive cultivation, and also high crop yield. Most papayas in the tropics can be harvested eight or nine months after sowing and yields can range from 60-100 t/ha/year for improved varieties. The ripe fruits has a delicate aroma and sweetness, and high contents of vitamins $\mathrm{A}$ and $\mathrm{C}$. There is a great diversity in the size, shape and quality of the fruit. In unselected germplasm or backyard trees, fruits are usually very large and not very palatable, but for varieties such as 'Solo' and 'Eksotika' specifically selected for export or up-market, they are usually small for convenient packaging and have much better taste and storage attributes [6]. Carica papaya L. is a very good example of a crop that is extremely vulnerable, but economically very important [5]. 


\section{MATERIALS AND METHOD}

\section{A. Plant Materials}

Hermaphrodite (elongated) papaya (Carica papaya L.) seed of Eksotika variety were obtained from Malaysian Agricultural Research and Development Institute (MARDI) at Serdang, Selangor. The seed of Carica papaya $L$. which were used in this research were obtained from the traditional market at Tanjong Malim, Perak, Malaysia.

\section{B. Chemicals}

The ingredients of MS basal medium, BAP (6 benzylaminopurine) and NAA (1-Naphthylacetic acid).

\section{Culture Condition}

Seeds were surface sterilized with $50 \%$ disinfectant for 10 minute followed by sterilizing with $40 \%$ sodium hypochlorite for 10 minutes. Then they were washed 3 times in sterile distilled water and germinated in a jar containing MS medium without vitamins, myo-inositol and PGRs with $1.5 \%$ sucrose and $0.8 \%$ agar at a destiny of 2 seeds per jar. All jars were labeled and placed on the cabinet in the tissue culture room at $23 \pm 10 \mathrm{C}$ with 16 hours light and eight hours dark photoperiod. The aseptic seedlings from the germinated seeds were placed onto a sterilized petridish. Each part of the papaya explants (root, stem and leaf) were cut into small segments before being cultured. All explants were cultured onto MS media with various hormones concentrations. The jars were labeled according to the treatments. Lastly, the jars were arranged on the culture rack in tissue culture room at $23 \pm 10 \mathrm{C}$ with 16 hours of light and eight hours of dark photoperiod. After 10 days the induced callus were weighted (fresh weight) and the frequency of callus, shoot regeneration and root formation were calculated.

\section{RESULT AND DISCUSSION}

In plantlets regeneration and callus induction studies, three explants of Carica papaya L.; root, stem and leaf were used as the samples which the amount for each explant was 16 for each treatment. In all treatments, MS (Murashige and Skoog, 1962) media was used as the basic culture media. MS media culture that was used in the experiments was also combined with the several plant hormones; Benzylaminopurine (BAP) and Napthalene Acetic Acid (NAA).

There were 16 various concentrations and combinations of BAP and NAA (plus one MS basal media as control). All the explants cultured were incubated in the culture room at $23 \pm 1$ 0C with 16 hours light and 8 hours dark. Observations were made every two weeks for 8 weeks.

Analysis of variance (ANOVA) was conducted that examined the effect of treatment (Concentration and combination of Benzylaminopurine (BAP) and NapthaleneAcetic Acid (NAA)) and types of explants on number of shoots. There was a statistically significant interaction between the treatment (Concentration and combination of Benzylaminopurine (BAP) and Napthalene-Acetic Acid
(NAA)) and types of explants on number of shoots, F (30, 1392) $=24.221, \mathrm{p}<0.05$.

Figure 1 shows the best response for the formation of shoots from stem explants were MS media supplement with $2.0 \mathrm{mg} / \mathrm{L}$ BAP. It showed that the function of BAP hormone was essential in the formation of shoots from the explants. This is in line with Teo [12] who stated that the function of cytokinins could stimulate the formation of shoot. Observations by other authors Panjaitan, Aziz, Rashid and Saleh, [8] stated that the mixture of $1.0 \mathrm{mg} / \mathrm{L}$ BAP with 0.05 $\mathrm{mg} / \mathrm{L}$ NAA produced the highest mean number of shoots per explant (73.3). Enhancement of the BAP concentration up to $1.0 \mathrm{mg} / \mathrm{L}$ resulted in increased number of shoots produced per explant.

Roy, Roy and Hakim [9], explained that the lateral bud of Carica papaya $\mathrm{L}$. gave the highest percentage of shoot induction with MS media containing $1.0 \mathrm{mg} / \mathrm{L} \mathrm{BAP}$ and 0.2 $\mathrm{mg} / \mathrm{L}$ NAA with $34.2 \pm 4.22$ shoots regenerated. Meanwhile, Ogunsola and Ilori [7] claimed that the bud number increased to be highest in MS medium with $3.0 \mathrm{mg} / \mathrm{L} \mathrm{BAP}+0.1 \mathrm{mg} / \mathrm{L}$ NAA in $80 \%$ of the culture. Islam, Rahman, Hossain \& Joarder [4] said that the maximum result for shoot formation were obtained using BA at $0.5 \mathrm{mg} / \mathrm{L}$ and NAA at $0.1 \mathrm{mg} / \mathrm{L}$ with $48.4 \pm 3.0$ shoots per explant.

In root induction, there was a statistically significant interaction between the treatment (Concentration and combination of Benzylaminopurine (BAP) and NapthaleneAcetic Acid (NAA)) and types of explants on number of root, $F(30,1392)=10.150, p<0.05$. Figure 2 shows the highest response was obtained when the MS media added with $0.5 \mathrm{mg} / \mathrm{L} \mathrm{BAP}+2.0 \mathrm{mg} / \mathrm{L}$ NAA was used to culture stem explants. So, it can be explained that NAA hormone played important role in the development the root from the explants. Teo [12] stated that the function of auxin could stimulate the formation of adventitius roots. Da Silva [11] claimed that the rhizogenesis was possible from young papaya leaves in response to several auxins, but not to phloroglucinol.

The experiment with the use of auxin hormones conducted by Sevik and Guney [10] also concluded that the auxin group hormones (IAA, IBA and NAA) did not affected directly to the rooting percentage, but these hormones were detected affecting the morphological characteristics on the newly generated plants specifically on the root generation. Another research by Ogunsola and Ilori [11] stated that MS supplemented with $1.0-2.0 \mathrm{mg} / \mathrm{L}$ IBA $+0.1 \mathrm{mg} / \mathrm{L}$ BAP induced better rooting. MS medium supplemented with 2.0 $\mathrm{mg} / \mathrm{L} \mathrm{IBA}+0.1 \mathrm{mg} / \mathrm{L} \mathrm{BAP}$ was shown to be optimum for root induction.

In callus induction experiment, there was a statistically significant interaction between the treatment (Concentration and combination of Benzylaminopurine (BAP) and Napthalene-Acetic Acid (NAA)) and types of explants on weight of callus, $F(30,1392)=20.893, p<0.05$. Figure 3 shows the highest fresh weight for root explants was obtained when explants were cultured on MS media with $2.0 \mathrm{mg} / \mathrm{L}$ BAP 
$+1.0 \mathrm{mg} / \mathrm{L}$ NAA. Most of the callus colour was white and the structure of callus were friable. For stem explant, the highest fresh weight was obtained when explants were cultured on MS media with $0.5 \mathrm{mg} / \mathrm{L} \mathrm{BAP}+0.5 \mathrm{mg} / \mathrm{L}$ NAA. All the colour of callus from stem explants were cream with absolute friable structure. As for callus induction for both leaf explants, the highest fresh weight was obtained when explants were cultured on MS media with $2.0 \mathrm{mg} / \mathrm{L} \mathrm{BAP}+2.0 \mathrm{mg} / \mathrm{L}$ NAA. For leaf explant, most of the callus colour were cream and the structure of callus structure were friable.

Gana [3] stated that, in term of grafting, auxin promotes callus tissue formation, which merged the surfaces of the graft. Teo [12] explained that the addition of various concentrations of NAA (Napthalene Acetic Acid) and BAP (Benzyl Amino Purine) through in vitro methods effected significantly to the induction time velocity and viability of callus. The most optimal concentration was $3.0 \mathrm{mg} / \mathrm{L}$ NAA and $1.0 \mathrm{mg} / \mathrm{L}$ BAP. Usman, Fatima, Jaskani \& Khan [13] claimed that leaf blade with midrib explant with 2, 4-D (2.5 $\mathrm{mg} / \mathrm{L})$ was the best callus growth with $0.1817 \mathrm{~g}$. Panjaitan et al. [8] stated that the highest amount of callus (90\%) was obtained in treatment containing $0.20 \mathrm{mg} / \mathrm{L}$ NAA without BAP.

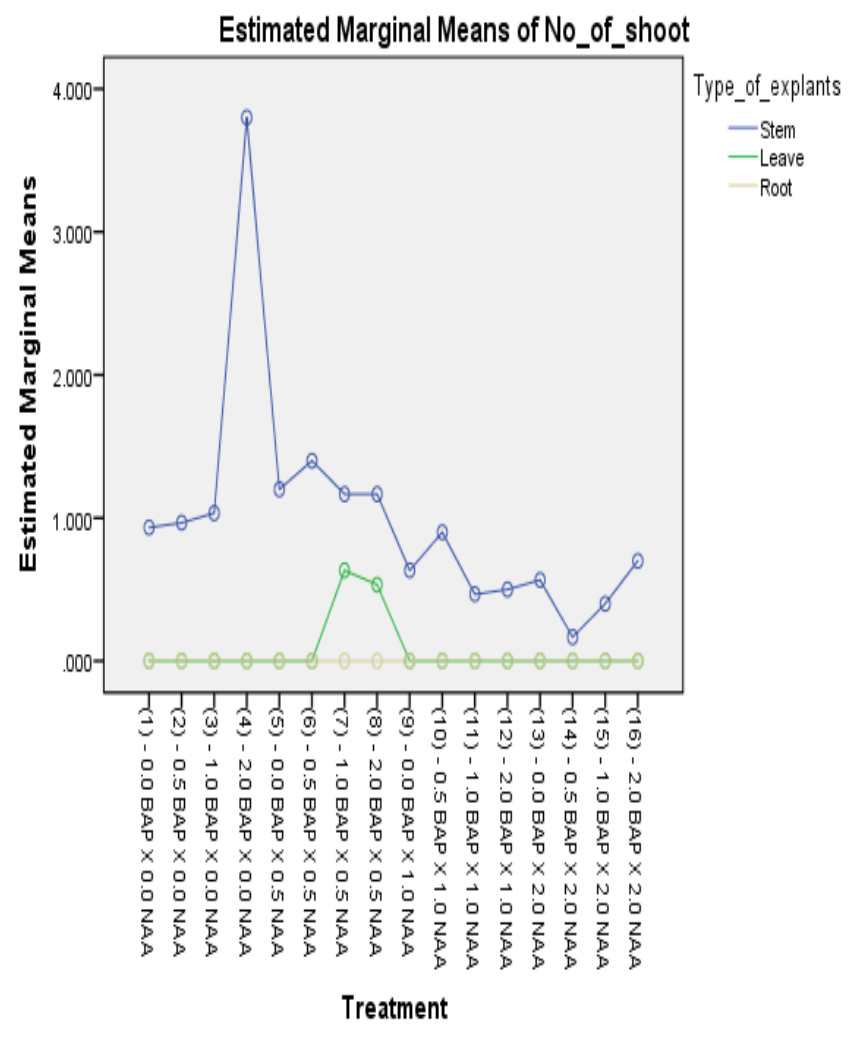

Fig. 1 Effects of Different Concentration and Combination of BAP and NAA on Stem, Root and Leaf Explant Cultured on MS Medium on Shoot Regenaration

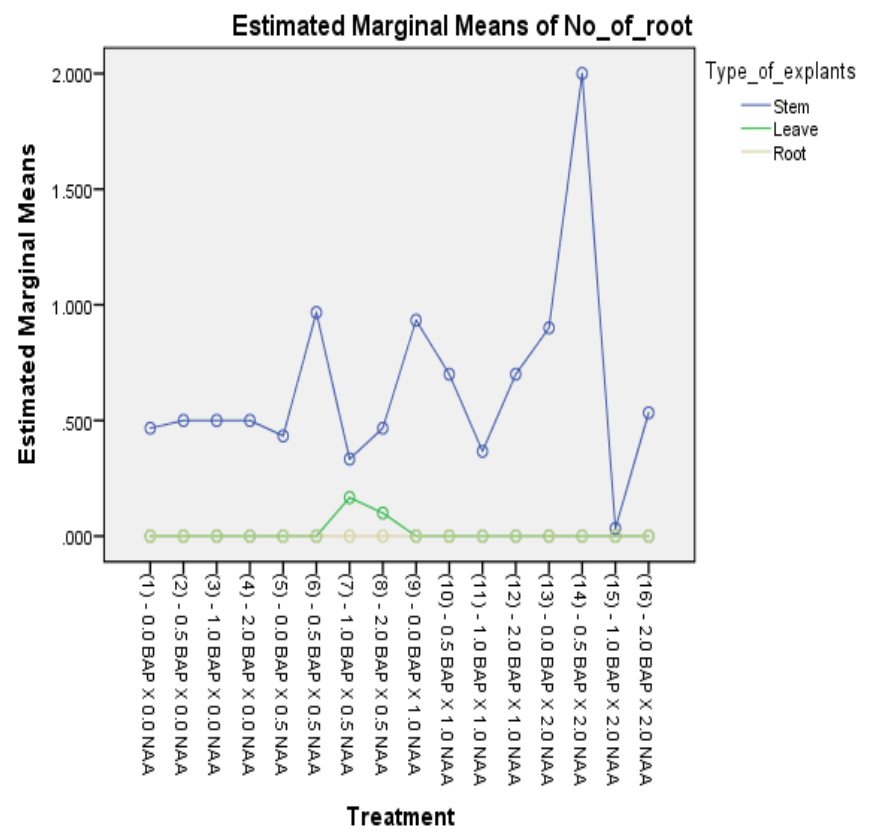

Fig 2. Effects of Different Concentration and Combination of BAP and NAA on Stem, Root and Leaf Explant Cultured on MS Medium on Root Formation

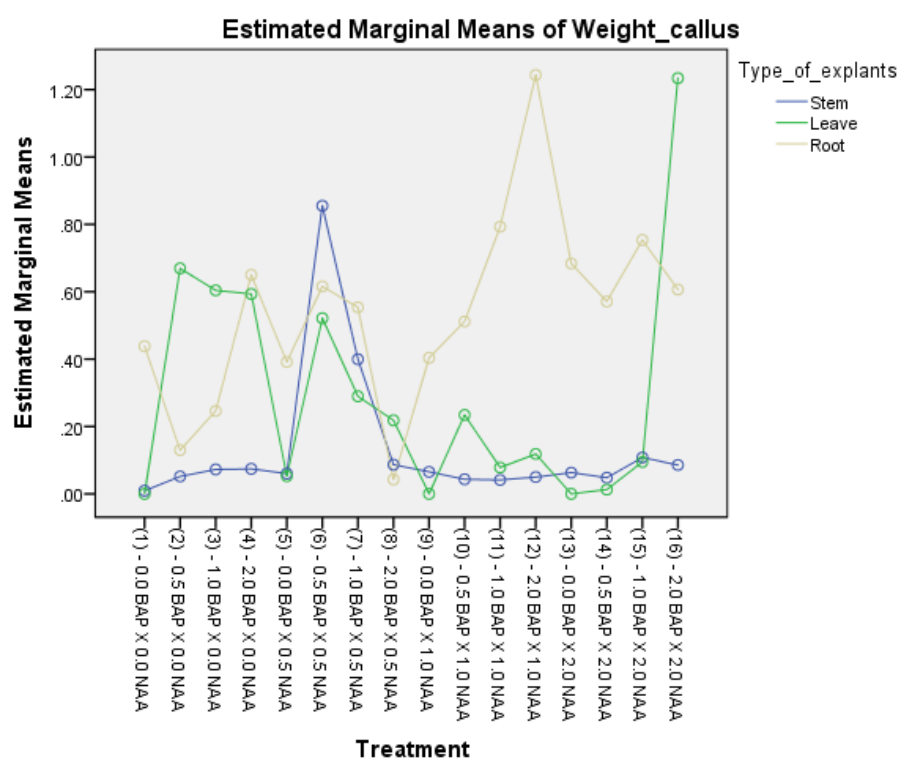

Fig. 3 Effects of Different Concentration and Combination of BAP and NAA on Stem, Root and Leaf Explant Cultured on MS Medium on Callus Induction 

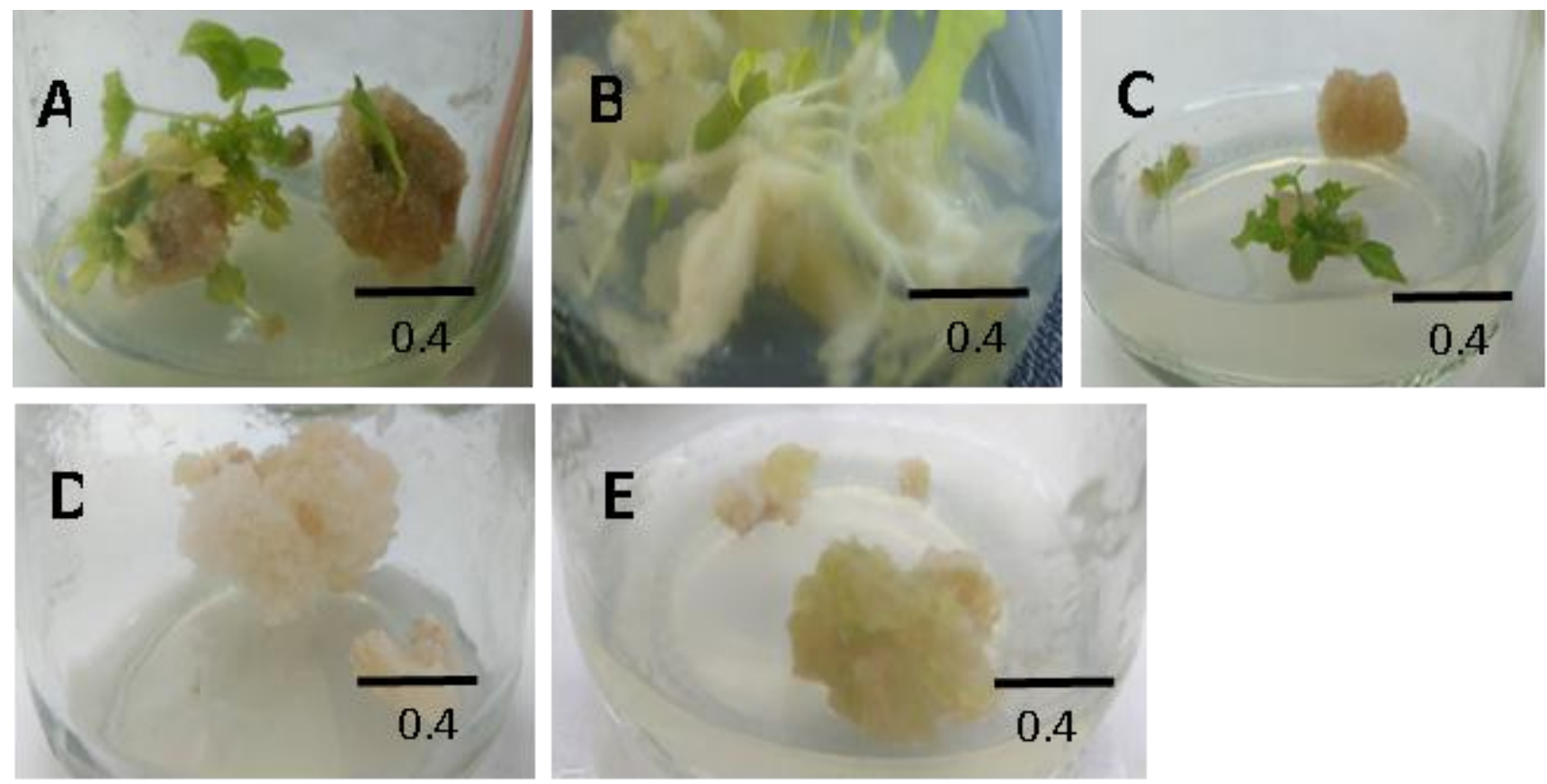

Fig. 4 (A). Shoot regeneration on stem explant cultured on $2.0 \mathrm{mg} / \mathrm{L}$ BAP (B). Root formation (C). Callus induction for stem explants (D). Callus induction for root explants (E). Callus induction for leaf explants.

\section{ACKNOWLEDGMENT}

The authors wish to express their gratitude to the Department of Agriculture Science, Sultan Idris Education University (UPSI), Perak, Malaysia for supporting this research.

\section{REFERENCES}

[1] FAOSTAT (2017). Food and agriculture organisation for the United Nations -Statistics online database. Available from http://faostat.fao.org [Retrieved on 25 April 2017].

[2] Federal Agricultural Marketing Authority, (2014). "FAMA marketing main statistic 2011, 5th Edition". Ministry of Agriculture and Agrobased Industry

[3] Gana, A. S. (2010). The role of synthetic growth hormones in crop multiplication and improvement. African Journal of Biotechnology 10(51), 10330-10334.

https://doi.org/10.5897/AJB10.301

[4] Islam, R., Rahman, S. M., Hossain, M., \& Joarder, O. I. (1993). In vitro clonal propagation of papaya (Carica Papaya L.). Pak. J. Bot,25(5), 189192.

[5] Malaysian Agricultural Research and Development Institute. (2014). Breeding horticultural crops @ MARDI. Kuala Lumpur: MARDI.

[6] Malaysian Agriculture Department. (2013). Menuai tanaman betik Carica papaya L. Malaysia: Malaysian National Library.

[7] Ogunsola, K. E., Iiori, C. O. (2008). In vitro propagation of miracle berry (Synsepalum dulcificum Daniel) through embryo and nodal cultures. African Journal of Biotechnology, 7(3), 244-248.

[8] Panjaitan, S. B., Aziz, M. A., Rashid A. A., Saleh, N. M. (2007). Invitro regeneration from shoot tip of field-grown hermaphrodite papaya (Carica papaya L. cv. eksotika). International Journal of Agriculture \& Biology,9(6), 827-832.

[9] Roy, P. K., Roy, S. K., Hakim, M. L. (2012). Propagation of papaya (Carica papaya L.) cv. Shahi through in vitro culture. Bangladesh J. Bot, 41(2), 191-195.

[10] Sevik, H., \& Guney, K. (2013). Effects of IAA, IBA, NAA and GA3 on rooting and morphological features of Melissa officinalis L. stem cuttings. The Scientific World Journal, volume 2013, http://dx.doi.org/10.1155/2013/909507

[11] Teixeira Da Silva, J.A. (2013). In vitro rhizogenesis in papaya (Carica papaya L.). J. Plant Develop, 20, 51-55.

[12] Teo, C. K. H (1992). Pengenalan teknologi kultur tisu tumbuhan. Pulau Pinang: Universiti Sains Malaysia.

[13] Usman, M., Fatima, B., Jaskani, M. J., Khan, M. M. (2002). Development of a callogenic protocol in papaya (Carica papaya L.) 1. In vivo grown vegetative explan

[14] Zulkarnain. (2014). Kultur jaringan tanaman. Jakarta: Bumi Aksara. 